\title{
CORRIGENDUM
}

\section{The financial cost of optimising blood pressure control}

T Shiner, L Simons, H Parkinson, A Khanbhai and DG Beevers

Journal of Human Hypertension (2005) 19, 849. doi:10.1038/sj.jhh.1001938

Correction to: Journal of Human Hypertension (2005); 19, 83-84. doi:10.1038/sj.jhh.1001778

Published online 16 September 2004

Since the publication of the above-mentioned article, it has been noted that two authors were omitted from the original author list.

The revised list of authors is given below:

T Shiner, L Simons, H Parkinson, G Nandhara, VJ Karthikeyen, A Khanbhai and DG Beevers 